\title{
The contribution of the European Union to global climate change governance: explaining the conditions for EU actorness
}

\author{
A contribuição da União Europeia à governança \\ da mudança climática global: explicando as condições \\ para a actorness da UE
}

CAROLINA B. PAVESE*

DIARMUID TORNEY**

Rev. Bras. Polít. Int. 55 (special edition): 125-143 [2012]

\section{Introduction}

From an early stage, the European Union (EU) has played what has often been considered a leadership role in global climate governance, pushing for ambitious international commitments. Yet, as the only regional organization member of the United Nations Framework Convention on Climate Change (UNFCCC) and the Kyoto Protocol (KP), the EU can be considered a sui generis international climate actor.

Sharing competences on climate politics with its member states, the EU's presence in the international climate regime does not replace but rather complements that of its 27 members. As a result, the EU's identity and role in the regime faces constraints that do not apply to any other party. Understanding EU engagement with global climate governance requires, therefore, considering the singular nature of EU's identity as an international actor, or actorness.

This article assesses the EU as an actor in the case of the international climate change regime, and is divided into three core parts. First, the article presents a brief overview of theoretical discussions on actorness that set the ground for this study. Second, the article explores two formal requirements for actorness, namely, external

\footnotetext{
* PhD Candidate in International Relations and Research Assistant at the Grantham Research Institute on Climate Change and the Environment, the London School of Economics and Political Science. The author would like to thank the Coordination for the Improvement of Higher Education Personnel (CAPES) for the financial support to her doctoral studies (c.boniatti-pavese@lse.ac.uk).

** $\mathrm{PhD}$ in International Relations, University of Oxford. During the writing of this article, Diarmuid Torney was a postdoctoral fellow at the Kolleg-Forschergruppe (KFG) "The Transformative Power of Europe," hosted at the Freie Universität Berlin. He is particularly grateful to Thomas Risse and Tanja Börzel (diarmuidtorney@ gmail.com).
} 
recognition and capability. It looks at the EU's membership of the UNFCCC and the KP and seeks to identify how the EU's status as the sole regional organization member of this regime affects formal external recognition of the EU as part of global climate governance. Next, considering capability as legal competences and institutional settings, the article assesses the power invested in the EU to act over climate issues. Identifying the strong intergovernmental nature of EU external climate policy, we then explore how this impacts the dynamics of internal decisionmaking process, and the external representation of the EU.

The final part of the article focuses on the aspects we claim influence EU's identity as an actor in practice: cohesion and opportunity. Analyzing the EU's engagement with the development of the international climate regime from the adoption of the Kyoto Protocol to Conference of the Parties 17 (COP-17) in Durban in 2012, we identify how the degree of external opportunity and the level of internal coherence have varied over time. The overall conclusion of the article points to a limited degree of formal conditions for actorness and an irregular pattern of opportunity and cohesion. Nevertheless, this article reveals that the EU has been able to overcome these constrains to a large extent, thus affirming its identity as an international climate actor.

\section{The EU as an actor in global climate governance: a theoretical overview}

The first attempt to formulate a theoretical framework for analyzing the EU's condition as an international actor dates back to the pioneering work of Sjöstedt, which recognized the European Community (EC) as "a genuine actor in the international actor" but claimed that the degree of actorness can vary according to the capability to deliver as an actor in each issue-area (Sjöstedt 1977, 4). Building on this work, Bretherton and Vogler (2006) argued that, rather than being a given and well-established attribute, the EU's condition as an actor emerges from an ongoing process and results from the interaction of a complex set of factors of internal and external nature, namely, (i) opportunity, (ii) presence, and (iii) capability.

Opportunity reflects the external structural context that creates the environment in which the EU can perform as an international actor - or not. Adopting a constructivist approach, the authors then consider as opportunity ideas, perceptions, and events that favor EU actorness, going beyond a focus on material conditions. The second element, presence, is defined as the ability of the EU to benefit from this opportunity not only to project its existence in the international arena, but also to exert external influence. Capability is established by internal conditions, and refers to the delegation of competences and the set of political instruments for EU external policies. It is underpinned by a certain degree of domestic legitimacy of EU action in combination with the shared understanding of the EU's ability to transform opportunities into valuable circumstances to 
project its presence in the international scene (Bretherton and Vogler 2006). As an evolving entity, the presence of the $\mathrm{EU}$ in the international scene varies in terms of degree and form, according to the issue-area at stake. Consequently, EU actorness cannot be expressed in a single and comprehensive definition; it requires a case-by-case assessment.

Taking a somewhat different approach, Jupille and Caporaso (1998) posit a theoretical framework to measure the degree in which the EU could be understood as an actor. According to their model, actorness comprises four components: (i) recognition, (ii) authority, (iii) autonomy, and (iv) cohesion. Recognition can be considered as a pre-condition for an actor's existence as it refers to the external acceptance by third parties of an actor's participation in world politics. The acknowledgement of this international presence can be de jure or de facto. That is to say actorness does not necessarily imply recognition formalized by diplomatic means or international law - it could also be determined in practice. The second criterion, authority, entails internal delegation of competence to an entity to perform in a given political area as an actor. Autonomy, the third element of actorness, corresponds to the institutional distinctiveness that makes the performance of an entity independent from that of its members. Finally, cohesion means ability to formulate and deliver policy preferences consistently between the entity and its member states.

Applying these analytical tools to measure EU actorness in environmental regimes, Jupille and Caporaso concluded that the EU does have a significant degree of actorness that favors its presence in the international arena. Fulfilling the criterion of external recognition, the member states invest some authority in the EU to perform as an international actor within these regimes. However, constrains over the EU's ability to deliver cohesion and autonomy underpin the prospects for a fully-fledged actorness within environmental regimes (Jupille and Caporaso 1998, 214-24).

Jupille and Caporaso's framework covers many important characteristics of actorness, but has limitations. Firstly, it is not the outcome of an in-depth analysis; secondly, nor are they applied to a specific regime part of the constellations of issues under the domain of environmental politics. Finally, these arguments were postulated in the late 1990s - arguably when environmental regimes were in an early stage of development. In the past 20 years certainly much has changed not only in terms of the dynamics of these regimes, but also on the EU's capacity visà-vis the four criteria of actorness presented by Jupille and Caporaso, and other scholars have more recently attempted to update and extend their analysis.

Considering the contributions and limitations of these approaches to actorness, this article builds on the existing literature and provides a theoretical and empirical account of the EU's identity in the specific domain of climate change. When selecting the criteria (or components) of actorness to be analyzed, the article borrows 
two elements of Bretherton and Vogler's approach, capability and opportunity, and two factors postulated by Jupille and Caporaso, recognition and cohesion.

The section that follows addresses the legal and institutional elements that provide the basis for the EU's identity as an international actor: recognition and capability.

\section{Assessing formal requirements for EU actorness: recognition and capability}

\section{EU membership of the international climate regime: the question of recognition}

The UN climate regime does not limit membership to nation-states. Rather, it allows the so-called Regional Economic Integration Organizations (REIOs) - like the EU - to take part in their framework under essentially the same terms as states (UNFCCC, Article 22). In terms of commitments, the UNFCCC declares that the responsibilities of REIOs cannot overlap that of its member states. Therefore, REIOs are bound to fully comply with agreements only when their participation in the regime replaces that of any of its member states. In the circumstances in which both REIO and its members join the regime, there should be a distribution of responsibilities among them and "the organization and the member States shall not be entitled to exercise rights under the Convention concurrently." Moreover, when that is the case, the REIOs should inform other parties of the scope of its competences over the matters addressed by the Convention (Article 22).

Having both the European Community and its 12 member states, at the time, signed the UNFCCC, EU engagement with the international climate regime falls into this latter category, i.e. they have what can be considered shared membership.

Another peculiarity of EU membership to the UNFCCC regards its voting rights. As defined by Article 18, a REIO cannot vote when its member states are exercising their voting rights, and vice-versa. Should a regional organization vote on behalf of their members, they have the same number of votes corresponding to their member states part to the UNFCCC (UNFCCC 1992). Hence, even if considered a fully-fledged member to the climate regime, the EU has restricted voting powers. In practice, this formal restriction on voting rights that grants the EU a treatment different from that of other parties (states) has no relevance for EU participation on climate negotiations, as agreements have always been promoted by consensus among the parties, and rules for voting have never been defined.

This "shared system" of representation has also reflected on the group position the EU occupies in terms of the Annexes of the UNFCCC and Kyoto Protocol, as well as on negotiating coalitions. The EU and 25 of its member states are included in the Annex I of the UNFCCC, the exceptions being Malta and Cyprus. Yet, only 
the first 15 countries to adhere to the EU, known as "the old members," and the Community feature in the Annex II; considered as economies in transition (EIT), the latest 12 states that joined the EU in the enlargement processes of 2004 and 2007 are excluded from this list. Finally, the EU and all its members are part of the Annex B of the Kyoto Protocol, being subjected to emission reduction targets.

In terms of negotiating groups in climate negotiations, the EU constitutes a group in itself, which stresses the need for internal cohesion. Partially reflecting this condition, the EU has taken unilateral actions in many rounds of the negotiations, reinforcing the view of the EU as a group in itself. Nevertheless, as the next section of this article further explores, the EU has had a mixed approach to negotiations, forming coalitions with different groups and/or bilateral alliances with other parties, on a circumstantial basis.

Overall, it can be concluded that the EU is formally recognized as an actor in the international climate regime. Furthermore, in addition to this de jure recognition, the fact that the other parties do pursue engagement with the EU within negotiations supports the claim of a de facto recognition. Having external acceptance, the EU meets the first pre-condition for its actorness.

\section{EU external climate policy: the question of capability}

Having external recognition means that the $\mathrm{EU}$ is allowed to take part in the international climate regime, sharing a space that would otherwise be exclusive to states. But does the EU have internal capability to pursue its role as an actor part of the in regime?

As a second formal requirement for EU actorness, capability is here understood as the delegation of competences and the institutional framework that legitimizes and provides the tools for the EU's action at the international arena as an actor per se. In order to assess the EU's capability in the realm of external climate politics, the next section breaks this concept into different elements. The analysis that follows first scrutinizes the EU's legal competences, and explores the internal decision-making process of EU external climate policy. Second, we then assess the EU's external representation at the multilateral level.

\section{Legal competences and decision-making}

The EU can act in areas in which it has legal competences delegated by member states under treaty provisions. The degree of power invested in the EU varies according to the issue, as competences can be exclusive or shared.

For a small number of areas, the EU has exclusive competence to adopt legally-binding acts, whereas member states can no longer legislate on these matters and must comply with EU legislation [Article 2 (1) Treaty on the Functioning of the European Union]. An example of exclusive EU competence is the Common 
Commercial Policy, which implies not only the setting of EU regulations over internal trade activities, but also a common EU external trade policy that must be endorsed by all member states. Hence, even if the EU and its 27 member states are part of the international trade regime - more specifically the World Trade Organization (WTO) -, they cannot adopt an individual approach at the multilateral level and must follow the EU's position.

EU legal competences over trade contrast with its power on environmental issues. Although the EU is recognized as a fully-fledged actor within the climate regime, sharing the same status as states, climate change is not an area of exclusive competence. As defined by Article 4 (2e) of the Treaty on the European Union, competences in the field of the environment are shared ${ }^{1}$ between the member states and the EU.

Hence, EU engagement within the international climate regime does not replace legal commitments undertaken individually by member states - rather it complements their participation. Consequently, compliance with these agreements is also a shared responsibility. ${ }^{2}$ Once ratified, mixed agreements become part of Community law, and the implementation and observation of the international obligations set by these accords fall under the legal jurisdiction of the European Court of Justice (Tabau and Maljean-Dubois 2010, 750). That is to say, in areas of shared competence the EU has limited power to act, and member states can still legislate as long as there is no EU legal act on the matter.

As a result of this legal framework, both the EU and its 27 member states are part of the climate regime, and are not only entitled to take part in international negotiations, but can, in principle, represent their own interests at the multilateral level (van Schaik 2010). Finally, as Delreux (2006, 244) contends, the EU needs to articulate a common position with its member states prior to international negotiations. The EU's mandate to act within these multilateral instances becomes limited to positions internally agreed.

The process of articulating this agreed position is negotiated in advance of each UNFCCC meeting, and consists of a number of steps. Negotiations on a common EU position start with debate at a technical level led by the relevant Council working group, namely the Working Party on International Environmental Issues - Climate Change (WPIEI-CC). The conclusions of these activities are taken to the Committee of Permanent Representatives - Comité des Représentants Permanents (COREPER). Once the COREPER has deliberated on the conclusions of the

1 Shared competence is one the three principles that determines the legal basis for EU external climate policy; EU decision-making within this area also needs to observe the principles of proportionality and subsidiarity, defined by Article 5 of the Treaty on European Union.

2 The problem, however, is that there is no clear line delimiting the distribution of competences betweenthe $\mathrm{EU}$ and member-states regarding compliance. The absence of a Treaty provision setting a legal framework for the distribution of competences in compliance of 'mixed agreements' was not addressed by the Lisbon Treaty, and remains a gap in the EU legal system. Consequently, the lack of a clear legal framework setting the limits of EU's authority and affects the dynamics of power between the EU and its member states. 
WPIEI-CC, it passes its recommendations to the Council of Ministers, meeting in its Environmental configuration. At this third stage, ministers from the $27 \mathrm{EU}$ member states hold a last round of debate, adopting a final position by consensus.

In recent years, climate change has become a more politicized issue within the EU agenda, leading to an increased engagement of the European Council in the decision-making of EU external climate policy. Thus, a fourth stage can be added to this process, with the European Council giving an extra input on some core - and more political - decisions regarding the EU's common position in this field (Schunz 2012, 206). The result of this process within the Council is a mandate for the EU to negotiate at the multilateral level.

Overall, the definition of climate change as an area of shared competence implies limited legal capability for EU actorness in global climate governance. Moreover, this sharing of responsibilities with member states reflects directly on the policymaking of EU external climate policy, as its strong intergovernmental nature denotes. Nonetheless, this limited scope for action does not prevent the EU from formulating its own approach to climate regime independently of its member states. But what are the implications of this shared competence status to EU representation at the multilateral level? In other words, can the EU speak as a single international actor?

\section{EU representation at the multilateral level}

Up to the entry into force of the Lisbon Treaty, on December 1, 2009, the EU's negotiating delegation at the international climate regime was formed by the "troika," composed by the European Commission, the Presidency of the European Council, and the incoming Presidency of the Council (Delreux 2011, 17-25). In 1996, the Commission formally requested a negotiating mandate from the Council, which was firmly rejected by the Council. This mixed system of representation has been managed with certain flexibility, enabling the EU to improve coordination and capacity to respond to negotiations. Over the past decade, the EU has emphasized the role of experts in the working groups of the Council, thus enhancing their participation in the deliberation of negotiation positions (Oberthür and Roche Kelly 2008, 38). Since 2004, a system of "issue leader" and "lead negotiations" has been in place. Consisting of experts from the Commission and several member states, these two groups have been in charge of representing the EU on the various multilateral negotiation groups that address specific issues of the climate regime (Oberthür and Roche Kelly 2008, 38).

The Lisbon Treaty brought significant changes to the EU institutional setting, most prominently through the establishment of a permanent presidency for the European Council, the creation of the European External Action Service (EEAS), and the decision that a Vice-President of the Commission should also perform the role of the new post of High Representative of the Union for Foreign Affairs 
and Security. Adding to this picture, Article 17 of the Lisbon Treaty establishes that "with the exception of the common foreign and security policy, and other cases provided for in the Treaties, it [the European Commission] shall ensure the Union's representation." Without further specifying, this provision creates legal basis for the Commission to exert a leading role in EU external representation in multilateral climate negotiations. However, being climate change an area of shared competence and of high profile in the EU's agenda, the Commission's mandate never materialized. Rather, member states vehemently insisted in maintaining the inter-governmental nature of EU representation.

In 2010, the Spanish Presidency of the Council broke a deal on EU representation in the post-Lisbon context, establishing that both the Commission and the Presidency of the Council had the mandate to speak on behalf of the EU, whereas internal coordination remains as a responsibility of the Presidency (Emerson et al. 2011, 83).The degree in which these recent changes have contributed to EU actorness within the international climate regime, in terms of external representation and internal decision-making, remains dubious. For Barnes (2010, 56-57), the Lisbon Treaty enhanced the role of the Commission in the development of EU external climate policy, and also the prospects of EU cooperation with other partners on this realm (Barnes 2010, 56-57). However, the tortuous path for the implementation of these institutional changes and the wide room for interpretation of the Treaty provisions have hindered the policymaking of EU external policies (Kaczyński 2011).

The analysis of the two formal criteria for actorness conducted in this section supports the claim that the EU does have external recognition, and institutional and legal basis for actorness in the international climate regime. Meeting the two prerequisites to actorness does not imply the EU actually delivers this actorness. Hence, having recognition and capability, the performance of the EU as an actor on global climate governance depends on two contextual elements: opportunity and cohesion. The next section scrutinizes these issues, providing an account of EU engagement on climate negotiations over the past decades.

\section{Assessing EU actorness in practice: the questions of cohesion and external opportunity}

Having analyzed the formal components of EU actorness - recognition and capability -, this section examines EU actorness in practice. As well as being dependent on formal characteristics discussed, EU actorness also depends on the degree of EU internal cohesion, and on the external opportunity structure of world politics. The analysis below draws out these two themes and explores how they have each varied over time since the mid-1990s. The aim is to trace the broad trajectory of European policymaking and to draw out how this has been a function of both the external opportunity structure and internal cohesion. 


\section{Target-setting and regime-building: the 1990s}

For most of the 1990s, EU climate policymaking was marked by a lack of cohesion. This is illustrated by the fact that efforts to formulate EU climate change policies during the 1990s were, for the most part, unsuccessful. The "flagship" policy proposal from the Commission, a carbon/energy tax, was rejected by the Council of Ministers in 1992 and there was little effort by way of internal policy development during the rest of the 1990s. However, the external opportunity structure at that time was broadly favorable. The end of the Cold War ushered in a new period of optimism in world politics, with hopes for a new liberal world order and enhanced possibilities for multilateral cooperation. Furthermore, there was increasing evidence that the US would not assume the kind of global leadership on environmental issues which it had undertaken in the 1970s and 1980s. This created a leadership vacuum on the climate issue.

This favorable external opportunity structure explains to a large extent the EU's success in shaping the international climate regime during the 1990s. The EU played a significant role in setting the outcome of negotiations on the UNFCCC, securing US participation in an agreement that differed significantly from the US position entering the negotiations in 1990-1991. However, this success was not reflective of EU actorness as such. During the final negotiations in 1992, the crucial compromise deal with the US was struck not by Portugal, the country holding the EU Presidency at the time, but rather by the UK acting to some extent independently of the broader EU effort (Haigh 1996).

The next phase of climate regime-building culminated in agreement on the KP. In March 1997, in preparation for the upcoming Kyoto conference later that year, EU heads of state proposed that, as part of a global agreement, industrialized countries should reduce their emissions of the three main greenhouse gases $\left(\mathrm{CO}_{2}\right.$, $\mathrm{CH}_{4}$, and $\mathrm{N}_{2} \mathrm{O}$ ) by $15 \%$ relative to 1990 levels by 2010 . They also agreed on how to divide up an overall EU target among the member states. Significantly, however, under this "burden-sharing" agreement, the sum of member state targets in fact only added up to roughly a 9.2\% reduction (Oberthür and Ott 1999, 67). Therefore, while there was superficial EU cohesion regarding this pre-Kyoto EU target, the EU effort was not underpinned by a deeper cohesion on how the EU and its member states would achieve this target. This reflects the fact that member states were deeply divided with respect to the priority they attached to combating climate change.

Nonetheless, the EU had some success in shaping the results of the Kyoto negotiations. The EU's main priority was to secure the participation of other industrialized countries in a legally-binding agreement with specific targets for each country. In this, the EU was successful: the KP set binding emission reduction or limitation targets relative to 1990 levels for Annex I Parties. However, the EU was forced to make several key concessions to the US on significant aspects of the 
Protocol design (Jordan and Rayner 2010, 65). One of the most significant issues in this regard was the inclusion of provisions for the so-called "flexibility mechanisms": the Clean Development Mechanism (CDM), Joint Implementation (JI), and Emission Trading. These concessions secured the agreement of the US delegation at Kyoto but stored up problems for the future, since the Clinton Administration in the US had no real chance of securing Congressional ratification of the KP.

Operationalizing the Kyoto Protocol - in particular the flexible mechanisms and the compliance procedures - was undertaken at the UNFCCC negotiations over the following years. This process was due to be concluded at COP-6 in The Hague in November 2000. However, these negotiations were characterized by strong conflict between the EU and the US, and by a significant lack of EU cohesion. On the final night of COP-6, the negotiations broke down spectacularly (Grubb and Yamin 2001, 261). UK Deputy Prime Minister John Prescott and French minister Dominique Voynet, as part of the EU Troika, initiated bilateral consultations with the US delegation while the COP was still meeting in plenary session. The EU Troika agreed a provisional deal on some issues with the US delegation, only to have it rejected by the larger EU group, reportedly led by Germany and Denmark (Rajamani 2006, 186-87). On the day after the negotiations were scheduled to conclude, COP-6 was suspended until May or June 2001.

\section{The EU response to US unilateralism: 2001-2005}

Entering the $21^{\text {st }}$ century, EU internal cohesion was boosted significantly by a change in the external opportunity structure. Arguably the most significant event in this regard in the early years of the $21^{\text {st }}$ century was the decision taken by the Bush Administration in March 2001 not to submit the Kyoto Protocol to Congress for ratification. The US decision to withdraw from the Protocol widened the window of opportunity for the EU at the international level, and also had a catalytic impact on EU internal cohesion.

In response to the US move, EU heads of state affirmed their commitment to the existing climate regime by taking a decision at the European Council in June 2001 to proceed with ratification of the Protocol in the absence of US support (European Council 2001). More broadly, the increasing US turn to unilateralism on climate change served to transform climate change from a sectoral policy into an issue of high politics and a core element of European identity. This transformation had a significant impact on domestic political coalitions within the EU. It strengthened the relative influence of those with a strong commitment to combating climate change by increasing the political appeal of leading the international climate negotiations and developing strong internal climate policies (Costa 2008, 537). This resulted in increasing internal EU cohesion with respect to climate policymaking. 
Around this time, another narrative began to take hold over the climate issue in Europe, driven particularly by the German and UK governments. Action to combat climate change was framed increasingly in terms of economic opportunities that would be generated as a result (Rayner and Jordan 2010, 102). This reconceptualization of the issue was reflected in the conclusions of the EU Council of Ministers as well. In contrast to the 1990s, when it merely acknowledged that action was technically and economically possible, from 2000 onwards, European governments began to pay more attention to the economic benefits associated with combating climate change (Oberthür and Dupont 2010, 86-87).

These factors combined to generate increasing internal cohesion among EU member states. The centerpiece of EU policymaking during this period was the EU Emissions Trading Scheme (EU-ETS). The decision to move forward with emissions trading represented a significant departure for the EU, since the EU strongly opposed the so-called flexible mechanisms during the Kyoto negotiations, and was driven significantly by the European Commission (Skjærseth and Wettestad 2007). Despite initial resistance from Germany and watering down by other member states, the EU Emissions Trading Directive (2003/87/EC) was adopted in 2003, which set caps on the emissions of large installations accounting for approximately $40 \%$ of total EU emissions. There was also a strong external dimension to the EU-ETS, brought about by the decision to "link" the EU-ETS to the other two flexible mechanisms of the Kyoto Protocol - the CDM and the JI. The EU-ETS, and market mechanisms more generally, became an increasingly central aspect of the EU's approach to international cooperation on climate change during the following years. Creating a "global carbon market" formed an important part of the EU strategy for the negotiations on a post-2012 regime (Council of the European Union 2009).

This growing internal cohesion and deepening domestic policymaking combined with a favorable external opportunity structure to generate enhanced EU international actorness. At the international level, EU attention in the early years of the $21^{\text {st }}$ century focused on securing entry into force of the Kyoto Protocol. US withdrawal from Kyoto in early 2001 not only galvanized European support for the protocol; it also left the stage clear for the EU to drive forward the process of operationalizing the Protocol.

Following failure in The Hague in December 2000, negotiations resumed in very different circumstances in Bonn in July 2001. In these discussions, the EU sought to defend the "environmental integrity" of the KP. However, other industrialized countries resisted and, under the agreement reached, the actual reduction would only be approximately $2.5 \%$ as opposed to the $5.2 \%$ reduction set out in the Protocol text (Ott 2001, 470). Nonetheless, reaching this level of agreement was an achievement, given what had gone before. The Marrakech Accords, which operationalized the Kyoto Protocol, were agreed at COP-7 in 
Marrakech in October-November 2001. The success of these negotiations was due in part to the increasing actorness of the EU.

Following the agreement at Marrakech, EU attention turned to securing entry into force of the Protocol. In order for this to occur, the Protocol had to be ratified by countries representing at least $55 \%$ of 1990 emissions of Annex I Parties. Since the US had withdrawn, the EU had to secure the ratification of the other industrialized countries with significant emissions, including Canada, Japan, and the Russian Federation. The Russian Federation, which accounted for 17.3\% of Annex I emissions in 1990, proved to be the most reticent. However, in late 2004 the EU brokered an informal deal with the Russian government under which the EU supported Russia's entry into the World Trade Organization in return for Russian ratification of the Kyoto Protocol (Damro 2006).

\section{Domestic success and international failure: 2006-2009}

The period from 2006 to 2009 was marked by growing internal EU cohesion with respect to climate change, but also by a much less favorable external opportunity structure for EU international actorness. Increased EU cohesion was underpinned by a number of factors. First, public concern regarding climate change increased significantly during this period. This built on growing scientific evidence which was synthesized in the Fourth Assessment Report of the Intergovernmental Panel on Climate Change (IPCC), released in November 2007 (Intergovernmental Panel on Climate Change 2007). While the growth of knowledge and understanding of climate change was not, of course, purely - or even predominantly - a European phenomenon; European public opinion was particularly receptive to this message. For example, a November 2009 Eurobarometer opinion survey found that 63\% of Europeans considered climate change a very serious problem, $24 \%$ considered it a fairly serious problem, and only $10 \%$ did not consider it a serious problem (European Commission 2009, 15).

Second, the economic case for taking action to combat climate change continued to be emphasized and strengthened by European governments. One of the most significant contributions in this regard was the Stern Review, commissioned by the UK government, which made the case that the short-term costs of mitigating climate change would be significantly less than the longer-term costs of inaction, and that action to mitigate greenhouse gas emissions should begin straight away (Stern 2006). Separately, the European Commission succeeded in linking the development of EU climate policy with a concern for Europe's energy security in the medium term (Adelle et al. 2009).

Third, a crisis in European integration in the mid-2000s provided another stimulus for EU climate policy. In 2005, the electorates of France and the Netherlands voted to reject a proposed EU Constitutional Treaty, which would 
have created a constitutional document for the EU. The resulting fallout created a political opportunity for climate policy. It became politically almost impossible to continue discussions on further EU institutional reform, which led to a search for more concrete projects where Brussels could show its ability to solve pressing cross-border policy problems. Thus, climate change had become "a savior issue for the EU itself" (van Schaik 2010).

This combination of factors underpinned increasing EU cohesion with respect to climate policymaking in the latter half of the 2000s. Against this background, EU heads of state agreed in March 2007 to set climate change targets for the period to 2020, as well as targets for energy consumption, renewable energy, and biofuels in transport fuels (European Council 2007). Building on a proposal from the European Commission in January 2008, a Climate and Energy Package was negotiated throughout 2008 by member states. A final agreement was brokered by French President Nicolas Sarkozy at the December 2008 European Council meeting, though member states succeeded in weakening the Commission's original package in several respects (Oberthür and Dupont 2010, 83).

The EU's 2020 climate targets and the Climate and Energy Package were framed explicitly as Europe's contribution to a post-2012 climate regime. However, despite this increased internal cohesion with respect to domestic policymaking, the international efforts of the EU had limited impact on the climate change negotiations in the period leading up to COP-15 in Copenhagen. In these negotiations, the EU pushed for a strong international agreement with binding targets for national emissions reductions, a timetable according to which those targets would have to be met, and robust enforcement and compliance mechanisms. Nonetheless, the EU was largely unsuccessful in achieving its aims.

The Copenhagen Accord - the text that emerged in the final day of the negotiations - was a strikingly minimalist final agreement which contrasted sharply with the EU's preferred approach to the global governance of climate change (UNFCCC 2010, 4-9). It included a goal of limiting the rise in global mean temperature to 2 degrees Celsius but contained no concrete commitments by any parties that suggested that this aspirational goal would be achieved. It took the form of a "pledge and review" agreement under which countries were invited to communicate their national targets for emissions reduction or limitation to the UNFCCC Secretariat. The Accord did not set out legally-binding targets for any countries, as the EU had sought, nor did it contain any reference to a "peaking year" for emissions from large developing countries. Moreover, in a symbolic blow to European leadership aspirations, the EU famously was "not in the room" during key negotiations on the final day of COP-15, in which the leaders of the US, Brazil, South Africa, India, and China decisively shaped the final outcome without EU involvement (BBC 2009).

The failure of the EU to successfully influence the international process was due significantly to the changing external opportunity structure. Three 
developments were particularly important. First, the US returned to the negotiating table. The inauguration of Barack Obama in January 2009 ended eight years of US disengagement from the climate change negotiations. Second, the preferences of an increasingly powerful coalition of actors diverge significantly from those of the EU. The US, China, and India altogether in particular attach much greater priority to national sovereignty and therefore support forms of international cooperation that involve much less intrusion into domestic policymaking. Third, the EU has become significantly less important with respect to global emissions. The EU-27 share of global emissions has decreased from approximately 19\% in 1990 to $11 \%$ in 2011. Other countries' emissions have increased over the same period - most strikingly that of China, whose share of global emissions has grown from $11 \%$ in 1990 to almost 29\% in 2011 (Olivier et al. 2012, 28). In short, the "window of opportunity" that facilitated the emergence and development of EU international actorness on climate change in the 1990s and early 2000s grew significantly smaller over the second half of the 2000s.

\section{EU retreat or resurgence: 2010-2012}

The outcome of the Copenhagen conference, and the EU's marginalization in the final negotiations, came as a blow to the EU's self-image as an international leader on climate change. Following on from this, 2010 saw a period of reflection concerning the EU approach to the international climate change negotiations and to its external relations more generally (European Commission 2010).

EU internal cohesion with respect to climate policymaking has declined in the period since Copenhagen for a number of reasons. First, EU leaders have focused considerably less attention on climate policy as they have become evermore preoccupied by the European sovereign debt crisis. Little room has been left for consideration of EU climate change policies at the highest political level. This contrasts sharply with the 2007-2009 period, during which climate change featured regularly on the agenda of European Council meetings.

Second, some newer member states have become increasingly assertive in expressing their opposition to strengthening EU climate policy. This has been led by Poland, which joined the EU in 2004 and which relies on coal for $90 \%$ of its energy generation. While the EU's climate change targets for 2020 and the Climate and Energy Package remain intact, efforts to increase the level of ambition of these measures, or to set targets for the period beyond 2020, have been thwarted. For example, in March 2012 and again in June 2012, Poland vetoed EU proposals for EU climate change targets beyond 2020 (Euractiv 2012). These factors have combined to reduce the EU's internal cohesion with respect to climate policymaking.

The external context has also moved on somewhat since Copenhagen. The opportunity structure still acts as a constraint on EU actorness, but shifting 
dynamics in the global politics of climate change have recently expanded the scope for EU influence. In particular, the role of China has changed in subtle but important ways. Widely portrayed as one of the causes of the minimalist outcome at COP-15, the Chinese government has undertaken a deliberate strategy of constructive engagement in the climate change negotiations during the period since. This was most evident at the Durban climate change conference in November-December 2011, during which the Chinese government announced mid-way through the two-week negotiations - for the first time - its willingness to be bound by a binding international climate agreement for the period from 2020 onwards (McGroarty 2011).

It was in the context of these broader shifts in global climate politics that the EU succeeded in playing a more significant and arguably more successful role, particularly at the Durban conference. It is true that the positions of other key actors have moved subtly but decisively towards the EU position, but EU actorness was also underpinned by a more nuanced and effective external diplomatic strategy. In particular, the European Commission and a number of EU member states participated in the period since Copenhagen in the Cartagena Group/Dialogue for Progressive Action, a group of 30 states seeking to develop a common vision and strategy for global climate action. Through such activities, the EU has been able to build alliances with other like-minded states in an informal setting.

COP-17 agreed to the launch of negotiations under a Durban Platform for Enhanced Action, which is tasked with negotiating a "protocol, another legal instrument or an agreed outcome with legal force under the Convention applicable to all Parties" (UNFCCC 2012). This is only a first step: negotiations are scheduled to be concluded by 2015, with a future agreement - if indeed agreement can be reached - due to enter into force in 2020. Nonetheless, the Durban represents an improvement towards the model of global climate change governance favored by the EU - namely a top-down international agreement with binding targets for all states. Moreover, the EU played a key role in bringing the final negotiations to a successful conclusion (Harvey 2011). That the EU succeeded in playing a significant role in shaping the Durban outcome seems surprising given the decline of EU internal cohesion over the period since 2009. However, EU actorness was facilitated by the more favorable circumstances provided by the shifting constellation of actors and interests in the global politics of climate change.

\section{Conclusion}

This article set out to analyze EU's identity as an actor part of the international climate regime by addressing the factors that define actorness: recognition, capability, opportunity, and cohesion. The scrutiny of these issues was divided into two parts. The first provided an account of the formal requirements for actorness, whereas the second part conducted an analysis of the elements that shape the EU's 
identity in practice. In both sections, the conclusion points out to the fulfillment of all the four criteria of actorness - albeit to a limited extent.

The first part demonstrated that the EU meets only partially the formal prerequisites (recognition and capability) for actorness. As a signatory of the UNFCCC and the KP, the EU has full membership of the international climate regime, which denotes complete external recognition of the EU as an actor in the regime at the same level as nation-states. Formal constraints are then of EU's capability to perform as such. As an area of shared competence, responsibility over climate change issues is divided between the Union and its 27 member states. In the absence of exclusive legal competence, EU policymaking on external climate policy has a strong intergovernmental nature, in which member states, operating through the Council, play a pivotal role. These internal dynamics reflect on the EU's representation in the multilateral area, where again member states set the boundaries to the EU's capability to act. Nevertheless, in spite of legal and procedural constraints, the EU has been able to forge mechanisms that, in practice, support its unitary engagement in the international climate regime. Overall, the first part concluded that the EU meets - to a certain extent - some of the minimum requirements for its actorness.

However, a significant implication of the analysis of the formal attributes of recognition and capability is that, because of the strongly intergovernmental nature of EU participation in the climate regime, EU actorness depends crucially on internal cohesion and the external opportunity structure. The second part of the article traced the development of EU participation in the climate regime, highlighting the importance of these two factors. Internal cohesion was limited during the 1990s, grew significantly over the 2000s, and has declined again in the period since 2009. By contrast, the external opportunity structure was most favorable for EU actorness during the 1990s and early 2000s, and grew less favorable in the period since 2008. In other words, internal cohesion and external opportunity are not correlated, and the changing patterns are helpful in explaining variation in EU actorness over time in the climate change regime.

Overall, this article cautions against viewing EU participation in the climate regime in simplistic, unitary terms. If we judge EU effectiveness and influence by the standards we apply to nation-states, we are likely to be disappointed by what we find. But viewed as a collection of nation-states with divergent interests and preferences, the EU contribution to the global governance of climate change has in fact been significant, though it has varied over time. The Durban climate change conference in December 2011 launched a new round of negotiations on a future climate change regime, and the EU was credited with playing a significant role in reaching a final deal at Durban. Despite shifting constellations of power and interest in the international politics of climate change, progress over the coming years in these negotiations is likely to depend in part on the continued ability of the $\mathrm{EU}$ to contribute to global action to combat climate change. 


\section{Bibliographic references}

Adelle, Camilla, Marc Pallemaerts, and Joana Chiavari. Climate Change and Energy Security in Europe. Stockholm: Swedish Institute for European Policy Studies, 2009.

Barnes, Pamela M. "The Role of the Commission of the European Union: Creating External Coherence from Internal Diversity." In The European Union as a Leader in International Climate Change Politics, edited by Rüdiger K. W. Wurzel and James Connelly, 41-57. London \& New York: Routledge, 2010.

BBC. "Key Powers Reach Compromise at Climate Summit." BBC News website, 19 December 2009. Availability: <http://news.bbc.co.uk/2/hi/europe/8421935.stm>, accessed 11 August 2011.

Bretherton, Charlotte and John Vogler. The European Union as a Global Actor (2nd edn.). London: Routledge, 2006.

Costa, Oriol. "Is Climate Change Changing the EU? The Second Image Reversed in Climate Politics." Cambridge Review of International Affairs 21, no. 4 (2008): 527-44.

Council of the European Union. "Contribution to the Spring European Council (19 and 20 march 2009): Further Development of the EU Position on a Comprehensive Post-2012 Climate Agreement - Council Conclusions.” Document 7128/09, 3 March 2009. Brussels.

Damro, Chad. "EU-UN Environmental Relations: Shared Competence and Effective Multilateralism." In The European Union at the United Nations: Intersecting Multilateralisms, edited by Katie Verlin Laatikainen and Karen E. Smith, 175-92. Basingstoke: Palgrave Macmillan, 2006.

Delreux, Tom. "The European Union in International Environmental Negotiations: A Legal Perspective on the Internal Decision-Making Process." International Environmental Agreements: Politics, Law and Economics 6, no. 3 (2006): 231-48.

Delreux, Tom. The EU as International Environmental Negotiator. Farnham: Ashgate, 2011.

Emerson, Michael, et al. Upgrading the EU's Role as a Global Actor: Institutions, Law and the Restructuring of European Diplomacy. Brussels: Centre for European Policy Studies, 2011.

Euractiv. "Poland Blocks EU's Zero-Carbon Plan.” Euractiv website, 18 June 2012. Availability: $<$ http://www.euractiv.com/climate-environment/poland-blocks-eus-zero-carbon-plnews-513368>, accessed 5 August 2012.

European Commission. "Europeans' Attitudes Towards Climate Change: Special Eurobarometer 322.” Document 2009. Brussels.

European Commission. "Communication from the Commission to the European Parliament, the Council, the Economic and Social Committee and the Committee of the Regions: International Climate Policy Post-Copenhagen: Acting Now to Reinvigorate Global Action on Climate Change.” Document COM (2010) 86 final, 9 March 2010. Brussels.

European Council. "Presidency Conclusions - Göteborg European Council, 15-16 June 2001.” Document SN 200/1/01 REV 1.

European Council. "Brussels European Council, 8-9 March 2007: Presidency Conclusions." Document 7224/1/07, 2 May 2007. Brussels.

Grubb, Michael and Farhana Yamin. "Climatic Collapse at The Hague: What Happened, Why, and Where Do We Go From Here?” International Affairs 77, no. 2 (2001): 261-76. 
Haigh, Nigel. "Climate Change Policies and Politics in the European Community." In The Politics of Climate Change: A European Perspective, edited by Tim O'Riordan and Jill Jäger. London: Routledge, 1996.

Harvey, Fiona. "Durban Talks: How Connie Hedegaard Got Countries to Agree on Climate Deal." The Guardian, 11 December 2011. Availability: <http://www.guardian.co.uk/ environment/2011/dec/11/connie-hedegaard-durban-climate-talks?intcmp=239>, accessed 5 August 2012.

Intergovernmental Panel on Climate Change. Climate Change 2007: Synthesis Report. Geneva: Intergovernmental Panel on Climate Change, 2007.

Jordan, Andrew and Tim Rayner. "The Evolution of Climate Change Policy in the European Union: An Historical Overview." In Climate Change Policy in the European Union: Confronting the Dilemmas of Mitigation and Adaptation?, edited by Andrew Jordan et al., 52-80. Cambridge: Cambridge University Press, 2010.

Jupille, Joseph and James A. Caporaso. "States, Agency, and Rules: The European Union in Global Environmental Politics." In The European Union in the World Community, edited by Carolyn Rhodes, 213-29. Boulder: Lynne Rienner, 1998.

Kaczyński, Piotr Maciej. "Swimming in Murky Waters: Challenges in Developing the EU's External Representation.” Document Helsinki.

McGroarty, Patrick. "China Shakes Durban Climate Talks.” The Wall Street Journal, 5 December 2011. Availability: <http://blogs.wsj.com/source/2011/12/05/china-shakes-durban-climatetalks/>, accessed 5 August 2012.

Oberthür, Sebastian and Hermann Ott. The Kyoto Protocol: International Climate Policy for the 21st Century. Berlin: Springer, 1999.

Oberthür, Sebastian and Claire Roche Kelly. "EU Leadership in International Climate Policy: Achievements and Challenges." The International Spectator 43, no. 3 (2008): 35-50.

Oberthür, Sebastian and Claire Dupont. "The Council, the European Council and International Climate Policy: From Symbolic Leadership to Leadership by Example.” In The European Union as a Leader in International Climate Change Politics, edited by Rüdiger K. W. Wurzel and James Connelly, 74-91. London \& New York: Routledge, 2010.

Olivier, Jos G.J., Greet Janssens-Maenhout, and Jeroen A.H.W. Peters. Long-Term Trend in Global CO Emissions: 2012 Report. The Hague: PBL Netherlands Environmental Assessment Agency \& EU Joint Research Centre, 2012.

Ott, Hermann. "The Bonn Agreement to the Kyoto Protocol - Paving the Way for Ratification." International Environmental Agreements: Politics, Law and Economics 1, no. 4 (2001): 469-76.

Rajamani, Lavanya. Differential Treatment in International Environmental Law. Oxford: Oxford University Press, 2006.

Rayner, Tim and Andrew Jordan. "The United Kingdom: A Paradoxical Leader?" In The European Union as a Leader in International Climate Change Politics, edited by Rüdiger K. W. Wurzel and James Connelly, 95-111. London \& New York: Routledge, 2010.

Schunz, Simon. "EU in the United Nations Climate Change Regime." In The European Union and Multilateral Governance: Assessing EU Participation in United Nations Human Rights and Environmental Fora, edited by Jan Wouters et al., 191-213. Basingstoke: Palgrave Macmillan, 2012. 
Sjöstedt, Gunnar. The External Role of the European Community. Farnham: Saxon House, 1977.

Skjærseth, Jon Birger and Jørgen Wettestad. EU Emissions Trading: Initiation, Decision-Making and Implementation. Aldershot: Ashgate, 2007.

Stern, Nicholas. The Economics of Climate Change: The Stern Review. Cambridge: Cambridge University Press and Cabinet Office - HM Treasury, 2006.

Tabau, Anne-Sophie and Sandrine Maljean-Dubois. "Non-Compliance Mechanisms: Interaction between the Kyoto Protocol System and the European Union." European Journal of International Law 21, no. 3 (2010): 749-63.

UNFCCC. "Report of the Conference of the Parties on its fifteenth session, held in Copenhagen from 7 to 19 December 2009" Document FCCC/CP/2009/11/Add.1, 30 March 2010.

UNFCCC. "Report of the Conference of the Parties on its Seventeenth Session, held in Durban from 28 November to 11 December 2011.” Document FCCC/CP/2011/9/Add.1, 15 March 2012.

van Schaik, Louise. “The Sustainability of the EU's Model of Climate Diplomacy.” In The New Climate Policies of the European Union: Internal Legislation and Climate Diplomacy, edited by Sebastian Oberthür and Marc Pallemaerts, 251-80. Brussels: Brussels University Press, 2010.

Received August 9, 2012 Accepted September 15, 2012

\section{Abstract}

As a regional organization, the European Union's role in global climate governance faces constraints that do not apply to other members of the United Nations Framework Convention on Climate Change (UNFCCC) and Kyoto Protocol. Addressing that uniqueness, this article provides a theoretical and empirical analysis of how the elements of actorness (recognition, capability, opportunity and cohesion) shape the EU's engagement with the international climate change regime.

Keywords: actorness; climate change; European Union.

\section{Resumo}

Como organização regional, o papel da União Europeia na governança global do clima enfrenta obstáculos que não se aplicam a nenhuma outra parte da Convenção-Quadro das Nações Unidas sobre a Mudança do Clima (CQNUMC) e do Protocolo de Quioto. Avaliando essa singularidade, este artigo fornece uma analise teórica e empírica de como os elementos de actorness (reconhecimento, capacidade, oportunidade e coesão) definem a participação da UE no regime internacional de mudanças climáticas.

Palavras-chave: actorness; mudança climática; União Europeia. 